\title{
Financial Decisions and Sustainable Cash Flows in Nigerian Manufacturing Companies
}

\begin{abstract}
* Japhet Imhanzenobe ${ }^{1}$ Semiu Adeyemi ${ }^{2}$

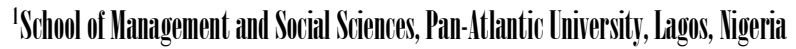
2Faculty of llanngement Sciences, Iniversity of Ligos, Lagos, ligeriia
\end{abstract}

Nigeria's over-reliance on oil revenues in recent years is one of the symptoms of the "Dutch disease"; a term that refers to the risk associated with excess economic dependence on natural resources. The unsustainable nature of this source of revenue has become evident in recent years, especially since the January 2020 oil prices crash that proceeded the Covid-19 pandemic. Since the end of the oil boom in 1983, the private sector business environment has become a harsh battleground for both large and small scale businesses as they compete for profit with limited resources and support from the government. Some studies have identified the manufacturing sector and tax system as vital factors that can influence future economic development (Aniyie, 2014; Ekeocha et al., 2012). However, this dream will be realistic only if the Nigerian companies generate enough cash flows to grow sustainably. Thus, the ability of manufacturing companies to generate sustainable cash flows is a prerequisite to their financial sustainability.

Oyewale and Adewale (2014) discovered that there is a low level of sustainable financial performance among Nigerian companies with reference to cash flows generated from asset utilization. 
From the end of the 1980s to date, many problems are responsible for this low sustainable financial performance of Nigerian companies. One major problem is scarcity and high costs of financing options (Atoyebi, Okafor and Falana, 2014). Due to high inflation and low currency value, few financial institutions are willing to give out loans and credit facilities without charging exploitative interest rates. This has given room for an unfair competition that creates market inefficiencies. The financial sector, which plays a crucial role in the economy and provides credit facilities and infrastructure to other sectors, has also been experiencing financial distress as can be seen from their inability to meet the loan-to-deposit ratio and cash reserve requirements in recent years (Komolafe, 2019; Nairametrics, 2020). This financial distress in the financial sector eventually rubs off on other sectors (Adeyemi, 2011). The scarcity of loan facilities has caused an increase in the costs of debt financing (leverage). Also, making use of external sources of finance may expose the company to some financial risks which might scare potential equity investors and cause current equity holders to demand higher dividend pay-out, thus reducing the sustainable cash flows that can be used for growth and expansion (Egboro, 2016).

This study aims to investigate the effect of financial decisions with regards to leverage, asset profitability, and dividend payout on the availability of sustainable cash flows as suggested by the free cash flow theory, and Modigliani and Miller theory in the Nigerian manufacturing sector context. The lack of sustainable cash flows in Nigerian companies has led to a decrease in the longevity of Nigerian businesses. Within the years 2009 and 2011 alone, more than 800 manufacturing firms had to shut down operations (Atoyebi et al., 2014). The consequences of this problem remain unsolved including the fact that the longevity of the few surviving companies in this industry may be short-lived. A useful step in solving the problem will be to identify the financial decisions that are crucial in maximizing sustainable cash flows of companies in the manufacturing sector since these cash flows can then be ploughed back as a source of internal financing for business expansion.

\section{LITERATURE REVIEW}

Several techniques have been used to evaluate the performance of businesses, one of which is the ratio analysis. According to Watts and Zimmerman (1990), studies in accounting have reported the signaling power of accounting figures and their usefulness in predicting business phenomena. In this study, we are interested in the financial ratios that assess both sustainable cash flow and its predictors.

\section{Measuring Sustainable Performance}

Sustainable performance refers to financial performance that is durable over time. It refers to the 


\section{Imhanzenobe \& Adeyemi}

ability of firms to generate real income that can help them sustain their financial status over a long period (Bowman, 2011; Jordão \& Almeida, 2017). Sustainable revenues have to be real and give an unbiased idea of the financial position and performance of the company. Financial performance tends to be biased when viewed solely from an accrual perspective. Companies' financial performance can be viewed from several perspectives, however, not all are sustainable. Previous studies conducted in other countries viewed sustainable financial performance mainly from the perspective of turnover and profit (Arora, Kumar and Verma, 2018; Costicã, 2014). However, this may have some challenges. Asset turnover may be sustainable only if the increase in sales can be traced to investment in assets. Though, there have been challenges in applying that method for non-profits who come to possess several assets with little or no cost e.g., donated assets (Akpan, Ahakiri and Ebaye, 2020). This will lead to an unearned increase in the turnover in relation to the cost of the total asset since the company will not invest in fixed assets until all available capacity is saturated, thus, not every growth in turnover is necessarily supported by new investments. This scenario is common in not-for-profit organizations that depend on donations to survive, but it is not limited to such organizations.

Also, managers may be tempted to sell off assets at the end of the period to give an apparent boost to turnover (especially when their compensations and bonuses are based on turnover indicators). This and other earnings management techniques have been a major limitation of measuring sustainable financial performance using turnover and profit. Profit has also been criticized as being susceptible to earnings management, especially when examined for short time ranges (Bhagat and Jefferis, 2005).

\section{-Minimizing Earnings Management Bias in Sustainable Performance Measurement}

Earnings management refers to the process of controlling reported earnings by tweaking its component variables. Management can achieve this in ways that may be ethical or unethical. Thus, Ghyasi (2017) categorized earnings management into two kinds; accrual items-based earnings management and actual based earnings management.

Many financial reporting standards established by the Financial Accounting Standards Board (FASB) and International Financial Reporting Standards (IFRS) propose a fair value system of measurement, thus leaving measurements of some items to managers' discretion. This has made room for subjectivity in the standard implementation (Clor-Proell, Proell and Warfield, 2014; McDonough, Panaretou and Shakespeare, 2020). The accrual items-based earnings management involves taking advantage of these subjective aspects of accrual-based accounting standards to postpone the recognition of losses and bring forward the recognition of income. This form of earnings management has been condemned as unethical by several professional bodies and regulators because it involves misrepresentation of financial position. 
Actual earnings management refers to the control of earnings by implementing policies that involve actual changes in operational and financial activity levels. This kind of earnings management has been encouraged by recent studies and deemed ethical, unlike the accrual items-based earnings management which takes advantage of loopholes in accounting standards (Dechow and Skinner, 2000; Healy and Wahlen, 1999; Roychowdhury, 2006).

\section{-Sustainable Cash Flows}

To minimize the effect of accrual items-based earnings management in our study, financial performance was considered from a cash flow perspective. The concept of free cash fl ow as a measure of sustainable earnings has been recognized as a crucial factor in analyzing the value created from a firm's operations, thus making it possible to overcome some of the limitations of accrual accounting (Payne, Wong and Payne, 2016; Castro and Chousa, 2006). Free cash fl ow is calculated by making some adjustments to the cash flow from operations (which can be found in the statement of cash flows) to exclude some items like capital expenditures and principal payments. The result can then be built on to produce ratios that portray a more realistic evaluation of the company by relating the free cash flow to enterprise market value or market value of equity (free cash flow yield).

There is a great deal of difference between profit and free cash flows, and every firm must ultimately produce these free cash flows. Thus, the free cash flow yield has grown in its use to measure the value of firms. The free cash flow yield is concerned first, with cash, and has the advantage of measuring the value of a company as a going concern as well as the ability to compare companies with different capital structures that are lacking in the more traditional ratios (Payne et al., 2016). The free cash flow yield is not easily subjected to accruals and so cannot be easily manipulated by managers. Thus, it reflects the real sustainable performance of the company in the period concerned.

Free cash flows are derived from the profitable operations of a company that is renewable (Mulford and Comiskey, 2005). It is less probable for a company with a suitable level of free cash flows to have financial sustainability issues, thus, making it an important parameter to gauge business success and failure.

A sample of listed companies in Nigeria showed a consistent decline in the average free cash flow yield from 2012 up to the point of having negative free cash flow yield (see Figure 1). This may suggest poor financial sustainability among listed Nigerian companies and, by extension, poor financial sustainability among Nigerian companies at large.

\section{Financial Decisions and Sustainable Cash Flows}

The conditions under which a company operates entails various configurations of the financial structure 


\section{Imhanzenobe \& Adeyemi}

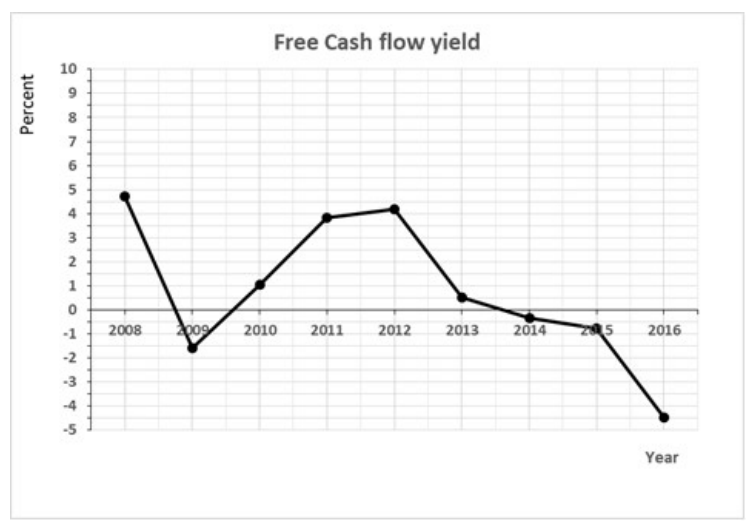

Source: Authors' Presentation

\section{Figure 1. Graph of Average Free Cash Flow Yield of Listed Nigerian Companies}

, as well as the profitability of its assets and how such profits are distributed. Given the dynamics of favorable and unfavorable variables, the optimum point which allows for the sustainable performance and development of the company must be found (Costicã, 2014).

The decisions that determine these configurations are at the heart of financial management and accounting. The financing decision explains how the assets of the company are being financed (with debt, equity, or retained earnings). The investment decision studies the net returns generated from the assets and capital expenditure of the company. The dividend decision addresses how much profit should be distributed or retained. Dividend decisions are often a function of negotiation between management and shareholders.

These decisions are interrelated with each other and an optimum combination of these decisions can maximize sustainable performance (Mougoué and Mukherjee, 1994). These decisions address some variables which, as in any experimental design, are consistent with existing theory.

\section{Theoretical Underpinnings}

The Free cash flow theory and the Modigliani and Miller theory of capital structure irrelevance are two theories that propose a relationship between the firms' performance and financial decisions revolving around dividend pay-out and debt usage respectively (Jensen 1986; Modigliani and Miller, 1958).

\section{-Free Cash Flow Theory}

The free cash flow hypothesis was proposed by Jensen (1986) who explained the free cash flow hypothesis as a solution to the agency problem. The theory suggests that companies tend to generate 
and retain more cash flows even when there are only little perceived growth opportunities. It suggests that managers of such firms, instead of distributing the excess cash as dividend to shareholders, may fall into cash abuse by investing in capital projects to the point of investing in projects with negative net present value (Ali and Yousaf, 2013; Kariuki, Namusonge and Orwa, 2015). Shareholders try to prevent this by pressuring managers to adopt dividend policies that promote a high dividend payout ratio, thus forcing managers to make use of debt in financing capital investment expenditure.

The amount of cash flows retained by managers is a function of the dividend policy which is a product of negotiation with the shareholders. The shareholders opt for an increase in dividend payout as a regulatory policy to reduce the amount of free cash flows available to mangers (Crutchley and Hansen, 1989; Giriati, 2016; Jensen, 1986). Also, when the availability of cash flows for financing capital projects is disrupted by higher dividend payout, debt financing (leverage) tends to increase.

The free cash flow theory also suggests that, in times of high growth opportunity, the shares of the company become more attractive to investors and thus can be sold at a premium. Managers can raise more funds through shares subscription. However, shareholders tend to react by putting pressure on managers to increase dividend pay-outs so as reap the reward of their investment in time (Ali and Yousaf, 2013; Kariuki et al., 2015).

\section{-Modigliani and Miller Theory of Capital Structure Irrelevance}

Debt is generally regarded as less risky from the investor's point of view (since they have primary claim on profits and are often secured with collaterals). Thus, the cost of debt tends to be lower than the cost of equity. However, the Modigliani-Miller theorem (M\&M) suggests that the value of a company (which is a function of the present value of its future cash flows and assets size) is independent of its capital structure (Modigliani and Miller, 1958; Nan, 2019).

According to Modigliani and Miller, the capital structure of a company is not a significant determinant of the future cash flows because, as the level of debt in the capital structure increases, the cost of equity will increase to cancel out the low-cost advantage of the debt in the long-run (Myers, 2001). In practical terms, the cost of equity increases because shareholders will demand even higher dividends as compensation for the increase in financial risk that comes with debt financing, and this will further reduce the net cash flows available for sustainable development (since dividends are frequently paid from cash flows). This creates a cycle of unsustainable financing and performance (Baker and Kilincarslan, 2018). Also, even when profit increases as a result of lower interest costs, shareholders naturally tend to demand more dividends (in the form of cash) when reported profit figures are high (even though reported profits figure may contain accrued income). This scenario is more apparent when the company has a large asset base (i.e., firm size) and easy access to the 


\section{Imhanzenobe \& Adeyemi}

capital market (Ferreira and Vilela, 2004; Harris and Raviv, 1990).

Both theories predict the nature of the relationship between the variables in this study. The a priori expectations of both theories are summarized in Table 1.

\begin{tabular}{cccc}
\hline Concepts & Variables & Free Cash Flow & M \& M Theory \\
\hline Leverage & Debt to Equity Ratio & Negative & Irrelevant \\
Asset Profitability & Asset Turnover & Positive & Positive \\
Dividend Policy & Dividend Pay-out Ratio & Negative & Irrelevant \\
Growth Opportunities & Tobin's Q & Negative & - \\
Firm Size & Log of Total Assets & Positive & Positive \\
\hline
\end{tabular}

Source: Authors' Presentation

\section{Table 1. A-priori Expectations of Theoretical Framework}

This study tries to test both theories in the Nigerian business environment. The study measures the financial performance of Nigerian manufacturing firms using free cash flows. The leverage, asset profitability, and dividend payout ratios were measured and their relationships with free cash flows were tested in line with the free cash flow and $M \& M$ theory to see if any or both apply in the Nigerian manufacturing sector context. The proposed relationships can be seen in the theoretical framework below (Figure 2).

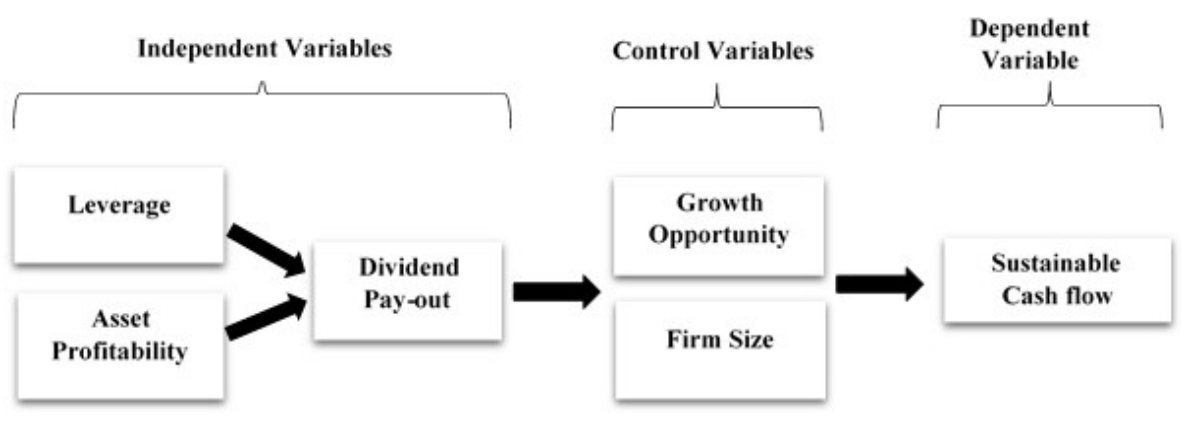

Source: Authors' Presentation

Figure 2. Conceptual Map of Financial Decisions Relationship with Free Cash Flows

\section{Hypotheses Development}

From the review of both theories, we can deduce that sustainable cash flows revolve around leverage, asset profitability, and dividend policy. These financial variables are very important in the formulation of financial management strategies and decisions as they provide questions like how the assets of a company are financed, how profitable the assets are, and how much of those profits are reinvested into the business? 
The company's capital structure is usually a function of the cost of the different sources of capital as well as negotiation between management and shareholders who arrive at conclusions after considering various forms of capital available. The investment and financing decisions made by management can affect the level of sustainable funds available to the company to finance its activities (Carpenter, 1995). Carpenter suggested that shareholders have two financing options; either restrict managers' access to sustainable cash flows by increasing dividend payout and forcing them to consider alternative sources of capital (financial constraints) or take the risk of maximizing the availability of sustainable cash flows to managers for expansion (free cash flows). The free cash flow theory suggests that the use of debt financing will cause shareholders to perceive extra financial risk, and so will want to be rewarded with a higher cash dividend which will reduce sustainable cash flows available to managers (Baker and Kilincarslan, 2018). On the other hand, the $M \&$ M theory suggests that leverage is irrelevant since the cost of equity (dividend payout) will only increase in a way that will net off the cheapness of debt financing.

To test these theories in the Nigerian manufacturing sector context, we question, what is the nature of the correlation between leverage and sustainable cash flows?

$\mathrm{H}_{01}$ : There is no relationship between leverage and sustainable cash flows.

The profitability of a company's assets is an important indicator of its going concern status (Bodie, Kane and Marcus, 2013). Asset acquisition decisions are evaluated based on the expected amount of revenue to be generated from it. Companies acquire funds to use them to invest in projects that will yield positive net returns. For companies to maintain a sustainable revenue stream, its assets must create value above their cost (Becerra, 2008; Kumar, 2016). Poor capital budgeting decisions, wastage, abnormal losses, and idle time all can lead to a reduction in turnover, thus harming the company's sustainability (Imhanzenobe, 2020). On the other hand, when capital investments in assets yield positive net returns, they could create enough cash flows both the settle shareholders' dividend appetite with enough to be ploughed back into the business.

This points us to another research question i.e., what is the nature of the relationship between asset profitability and sustainable cash flows?

$\mathrm{H}_{02}$ : There is no relationship between asset profitability and sustainable cash flows.

Dividend policies that encourage the retention of cash flows can help the company to be financially independent and sustainable (Pinkowitz, Stulz and Williamson, 2006; Opler et al., 1999). In reality, the dividend payout of the firm is a product of negotiation between the management and shareholders of 


\section{Imhanzenobe \& Adeyemi}

the company. Shareholders would rather have all the profit paid as dividends (100\% dividend payout ratio) due to the time value of money and other risks, while management would rather retain the entire profit and plough it back into the business ( $0 \%$ dividend payout ratio). The $M \& M$ theory suggests that dividend payout is insignificant since it increases with an increase in leverage in a way that leaves future cash flows fairly stable. Free cash flow theory, on the other hand, suggests a negative relationship between dividend payout and sustainable cash flows. This is because internally generated profits are commonly seen to belong to shareholders who thus, exercise their rights to such profit by frequently demanding high dividend payouts (Giriati, 2016). This happens even more frequently in companies where shareholders are risk-averse (e.g., in highly levered firms). However, in the longrun, this has been seen to cause even more agency problems (Baker and Kilincarslan, 2018).

To test the relationship between dividend payout and cash flows as suggested by the free cash flow theory and Modigliani and Miller theory, we ask a question, what is the nature of the correlation between dividend payout and sustainable cash flows?

$\mathrm{H}_{03}$ : There is no relationship between dividend pay-out and sustainable cash flows.

\section{METHODOLOGY}

The objectives of the study were to evaluate the existence and nature of the correlation between sustainable cash flows and its proposed predictors (Leverage, asset profitability, and dividend payout). This study was carried out using secondary panel data. The null hypotheses for the above objectives were tested for possible short or long-run relationships.

\section{Sample and Procedure}

Data for this study were obtained from the Bloomberg portal for financial information of the relevant companies. The population of the study included the manufacturing companies listed on the Nigerian Stock Exchange. A non-random sampling method was used based on the availability of data. A balanced panel data for 17 companies that had financial statements information available from 2008 to 2016 was extracted. The descriptive statistics of sample are shown in Table 2.

\section{Method of Analysis and Model Specification}

The panel unit root tests were carried out for each and all of the variables to identify short or long-run relationships. The Levin, Lin \& Chu test, the Im Pesaran and Shin test, and the Phillips - Perron test were used to test each variable for common and individual unit root respectively (i.e., nonstationarity)

The Kao residual cointegration test, and fully modified ordinary least square (FMOLS) technique 


\begin{tabular}{ccccccc}
\hline & FCY & DTE & AST & DPR & TBQ & FSZ \\
\hline Mean & 0.006498 & 49.28197 & 1.005363 & 0.566374 & 2.294844 & 10.64146 \\
Median & 0.023764 & 23.13745 & 1.014199 & 0.523568 & 1.699391 & 10.82818 \\
Maximum & 0.468847 & 232.3445 & 2.268054 & 2.116690 & 11.27745 & 12.18410 \\
Minimum & -1.058191 & 0.000000 & 0.232498 & 0.000000 & 0.275440 & 9.218804 \\
Std. Dev. & 0.161546 & 59.79881 & 0.443360 & 0.350578 & 1.940328 & 0.700074 \\
Skewness & -2.609822 & 1.150420 & 0.211411 & 0.739690 & 1.669296 & -0.274550 \\
Kurtosis & 18.30770 & 3.369274 & 2.531874 & 4.919848 & 6.532474 & 2.249273 \\
\hline \multicolumn{2}{l}{ Source: Authors' Presentation } & & & & &
\end{tabular}

Table 2. Descriptive Statistics

were used to test long-run relationships and evaluate the long-run coefficients, respectively. The hypotheses were tested using the following model below:

$$
\mathrm{FCY}_{\mathrm{it}}=\alpha_{0}+\alpha_{1} \mathrm{DTE}_{\mathrm{it}}+\alpha_{2} \mathrm{AST}_{\mathrm{it}}+\alpha_{3} \mathrm{DPR}_{\mathrm{it}}+\alpha_{4} \mathrm{TBQ}_{\mathrm{it}}+\alpha_{5} \mathrm{FSZ}_{\mathrm{it}}+\mu_{\mathrm{it}}
$$

\section{-Description of Variables}

Free cash flow yield was used to proxy sustainable cash flows. Free cash flow yield was calculated as the percentage of free cash flow per equity value (i.e., free cash flow divided by the market value of equity).

The independent variables that the study tests include leverage, asset profitability, and dividend policy, these were measured using debt-to-equity ratio, asset turnover ratio, and dividend payout ratio, respectively. The debt-to-equity ratio measures the mix of debt and equity components in the firm's capital structure (i.e., total debt/total equity). The asset turnover ratio is calculated as the total revenue divided by total assets for the period. The dividend payout ratio is calculated as the dividend paid divided by net profit. The empirical backing for the various measures can be found in Table 3 below.

Some firm-specific characteristics have been included in previous studies that test the $M$ \& $M$ theory as well as the free cash flow theory and thus were included as non-focal variables (Ali and Yousaf, 2013; Ferreira and Vilela, 2004). They include firm size and growth opportunities. Growth opportunity was measured with Tobin's $Q$ index. Tobin's $Q$ was calculated as the sum of the market value of equity and book value of debt divided by the book value of total assets. The firm size was calculated as the logarithm of total assets. According to Ali and Yousaf (2013), economies of scale on cash flows for regular transactions exist such that big companies tend to retain lower free cash flows than small ones. This may be because big companies can more easily get access to external finance than smaller ones (Baker and Kilincarslan, 2018). Ferreira and Vilela (2004) believe that, since large firms have a higher degree of shareholders dispersion, managers have superior discretion and so 


\section{Imhanzenobe \& Adeyemi}

\begin{tabular}{|c|c|c|}
\hline Variables & Operational Measures & Justification \\
\hline Sustainable cash flows & Free Cash Flow Yield (FCY) & $\begin{array}{c}\text { (Kadioglu and Yilmaz, 2017; } \\
\text { Payne, Wong, and Payne, 2016) }\end{array}$ \\
\hline Leverage Structure & Debt to Equity Ratio (DTE) & $\begin{array}{l}\text { (Carpenter, 1995; Jensen, 1986; } \\
\text { Khan, Kaleem, and Nazir, 2012) }\end{array}$ \\
\hline Asset Profitability & Asset Turnover Ratio (AST) & $\begin{array}{l}\text { (Ajmal, 2018; Baraja and Yosya, } \\
\text { 2019; Najid and Rahman, 2011) }\end{array}$ \\
\hline Dividend Policy & Dividend Payment Ratio (DPR) & $\begin{array}{c}\text { (Giriati, 2016; Karpavičius and } \\
\text { Yu, 2017; Vogt, 1994) }\end{array}$ \\
\hline Growth Opportunity & Tobin's Q (TBQ) & $\begin{array}{l}\text { (Kogan and Papanikolaou, 2014; } \\
\text { Lang, Ofek, and Stulz, 1996; } \\
\text { Smith and Watts, 1992) }\end{array}$ \\
\hline Firm Size & Logarithm of Total Assets (FSZ) & $\begin{array}{l}\text { (Ali and Yousaf, 2013; Babalola, } \\
\text { 2013; Ferreira and Vilela, 2004; } \\
\text { Wällstedt, Grossi, and Almqvis, } \\
\text { 2014) }\end{array}$ \\
\hline
\end{tabular}

Table 3. Variables'Specification and Justification

can hold more cash for speculative and precautionary motives. Also, growth opportunity was included because it plays an important role in the dividend policy decision of any firm that is listed on a stock market. When growth opportunity is high, shareholders want more dividends and this may reduce cash flows.

\section{RESULTS}

\section{-Descriptive Statistics}

Before estimating the relationship between the variables, some confirmatory correlation tests were done. Following the suggestions of Linares-Mustarós, Coenders and Vives-Mestres (2018), a correlation matrix was constructed to confirm the absence of multicollinearity among the regressors as shown in Table 4 (see Appendix-I). The table shows that there is an absence of multicollinearity with all the correlation coefficients having absolute values less than the 0.70 benchmark. This confirms that each of the independent variables truly measures different and uncorrelated aspects of financial performance. Models that are developed using distinct variables (absence of multicollinearity) tend to be more parsimonious. Thus, we can affirm that the concepts measured using each of the selected variables are unique in comparison with those of the other variables.

The mean free cash flow yield of 0.60 percent shows a poor level of sustainable cash flows among sample firms (Table 2). The average dividend payout was as high as 57 percent. The average debt to equity ratio was about 49.3 percent with some companies having as high as 232 percent. Both theories stipulate that shareholders tend to increase dividend demand when leverage increases. 
Although the $M$ \& $M$ theory suggests that this increase is not to a significant degree while the free cash flow theory believes the increase is significant. However, the correlation analysis shows that the relationship between leverage and dividend payout is negative and partially significant $(p<0.1)$. This indicates that shareholders demand less dividend when leverage increases. This may be due to the need to make more funds available to managers for future debt repayment and to avoid bankruptcy. Average asset turnover performance depends on the average of the industry and previous trends. However, the average asset turnover of 1.005 times is poor compare to the common industry minimum benchmark of 1.50 . This could hint that the poor level of free cash flows may partly be a result of poor choices of asset investment and maintenance. Also, the strong and positive significance of the correlation between asset turnover, growth opportunities, and dividend payout $(p<0.01)$ confirms that shareholders demand more dividend when asset profitability increases and when market prices of their shares increase (high growth opportunities). This aligns with the suggestions of the free cash flow theory more than those of the $M \& M$ theory.

The panel unit root test was also conducted on all the variables to check for stationarity (Table 5see Appendix-II). The Levin, Lin and Chu test, the Im Pesaran and Shin test, and the Phillips-Perron test were used to test for common and individual unit root respectively. The test statistics were significant at 1 percent, indicating that the variables are stationary at first difference.

This result suggests the possibility of a long-run relationship among the variables. The hypothesis of a possible long-run relationship was further investigated using the Kao residual cointegration test.

\section{-The Kao Cointegration Test}

The Kao residual cointegration test (Kao, 1999) was used as a preliminary test to affirm or reject the hypothesis of the existence of any long-run relationship among the variables (Table 6-see AppendixIII). The null hypothesis is that a long-run relationship does not exist among the variables. The test reported a $t$-statistic of -2.76 and a $p$-value less than 0.05 , thus we reject the null hypothesis of the absence of long-run relationship (i.e., a long-run relationship exists).

\section{-Panel Cointegration Coefficient Estimation}

Further steps were taken using the fully modified OLS method (FMOLS) to estimate the long-run coefficients (Table 7-see Appendix-IV). The model explains up to 55.23 percent of the long-run variation in the free cash flow yield. The debt to equity and dividend payout ratios were both negatively significant in the model with $p$-values less than 0.01 while asset turnover was positively significant with a $p$-value of less than 0.01 . This is because an increase in asset turnover increases the amount of 


\section{Imhanzenobe \& Adeyemi}

cash profit available to be retained by managers or distributed to shareholders as dividends. Meanwhile, contrary to the $M$ \& $M$ theory, leverage and dividend payout ratios were found to be negative and significant suggesting that increase in debt levels and dividend payments will reduce the free cash flow yield. As said earlier, the relatively low average asset turnover may suggest that this negative relationship between leverage and free cash flow yield may be due to poor investment decision made with funds acquired from debt financing by managers as suggested by the free cash flow theory and confirmed in previous studies (Akinleye and Dadepo, 2019; Imhanzenobe, 2019). Debt repayment and legal fees may also be factors since the estimates are in the long-run.

\section{-Test for Cross-Sectional Dependence}

The Breusch-Pagan chi-square test (Breusch and Pagan, 1980), as well as the Pesaran lagrange multiplier and cross-sectional dependence (Pesaran, 2006) tests, were carried out on the FMOLS model (Table 8-see Appendix-V). The Pearson cross-sectional dependence tests reported test statistics of about -0.28 and $p$-value of 0.78 while the Breusch-Pagan chi-square test reported test statistics of about 57.35 and $p$-value of 0.99 . The null hypothesis of cross-sectional independence was accepted since $p$-values were greater than 0.05 . This confirms that the variables of the companies in the sample were uncorrelated across cross-sections.

\section{DISCUSSION}

The debt-to-equity ratio, as a measure of the leverage, was found to have a negative and significant influence on sustainable cash flows in terms of free cash flow yield. This finding is in line with that of Maheshwari and Rao (2017), and Ali and Yousaf (2013) but goes against that of Kariuki et al. (2015), who found leverage to be a positive and significant determinant of cash flows. This result supports the suggestion that the use of debt as a means of increasing cash flows available to managers will increase the financial risk and future debt obligations and thus reduces cash flows in the long-run (Ferreira and Vilela, 2004). The high level of debt usage accompanied by low sustainable finance (free cash flows) and high dividend payout, as can be observed in Table 2, could suggest that the funding gaps are compensated using debt financing which could harm the financial sustainability of businesses. In the Nigerian business environment, which has been recently characterized by a high rate of inflation and cost of borrowing, the result of the analysis further shows that companies can better improve their sustainability position when capital projects are financed with retained cash flows as this will reduce debt obligations and the probability of bankruptcy.

The dividend payout ratio was found to have a negative significant impact on the free cash flows, as suggested by Ferreira and Vilela (2004). This result may provide a hint that one of the reasons for 
the lack of sustainable cash flows among Nigerian manufacturing companies could be high dividend payouts demanded by shareholders. Sustainable cash flows of companies may be improved when a higher percentage of the profits generated from the productivity of the company's assets, instead of being paid out as dividend, is retained for use in financing expansion projects. This is because internally generated cash flows improve the financial independence of the company as well as reduces delays in project execution that may be caused by the rigor of sourcing for and evaluating different financing options. This finding goes against those of Singh and Misra (2019), Maheshwari and Rao (2017), Ali and Yousaf (2013), and Ozkan and Ozkan (2004). This could be because these studies used dummy variables of 1 and 0 to measure dividend. This measure does not consider the magnitude of the dividend payment or relate it to the actual earnings from which the dividend was paid, thus limiting its ability to provide an accurate prediction of the actual relationship.

The asset turnover ratio was found to be positive and significant in determining the free cash flow yield. This confirms the prediction that businesses have to operate at a profitable level of activity before the firm can attain sustainable cash flows. Assets have to be utilized efficiently and profitably to generate positive cash flows for the entity. These positive cash flows form part of the profit for the period and are then retained or paid out as dividends to shareholders.

The relationship between growth opportunities (Tobin's $Q$ ) and free cash flow yield was found to be negative. The result is similar to that of Kariuki et al. (2015), and Ali and Yousaf (2013). This aligns more with the idea suggested by the free cash flow theory proponents, that managers tend to hold more cash (free cash flows) when the firm has low growth investment opportunities available, causing them to invest in projects with negative net present values (Singh and Misra, 2019). Firm size effect was found to be positive, confirming the suggestions of Ferreira and Vilela (2004) that managers of large firms have a superior discretion (due to higher shareholders dispersion), and so can hold more cash for speculative and precautionary motives.

\section{CONCLUSION}

The quest for sustainable performance among Nigerian companies has intensified in recent years with many companies shutting down due to lack of cash flow sufficiency. Cash flows have become an important aspect of firm performance and become a major proxy for the financial sustainability of companies. Managers have become more concerned about the level of free cash flows in recent times as this represents the pool of sustainable finance. The $M \& M$ theory and the free cash flow theory propose several variables that affect the sustainable cash flows of firms. Some of these variables, which were examined and analyzed in this study, include leverage, asset profitability, and dividend 


\section{Imhanzenobe \& Adeyemi}

policy. Growth opportunity and firm size were also included as control variables. Analysis of these variables in the Nigerian context proves that the use of debt to close the gap in financial requirements for investment expenditure ought to be minimized as poor investment decisions and debt repayments could reduce the sustainable fund available to managers.

Debt financing can be detrimental, especially in a business environment like Nigeria's, which is characterized by cost-push inflation and relatively stable market size for goods and services (thus stable demand which causes high price sensitivity). Financial institutions have increased their credit requirements because companies that venture into borrowing are often not able to recoup the capital and interest within the duration specified in the agreement. Default risks, on the part of borrowers, have led several banks to increase their lending rates and tighten their credit terms, thus making debt a less preferable method of financing asset acquisition. Also, many other informal lending institutions use these formal institutions as the benchmark for their lending rates. As a result, debt financing within the Nigerian business environment is not advisable, and thus companies should encourage more internal financing.

Companies that payout dividends are often perceived to be more sustainable than others that don't. However, analysis from this study may prove otherwise with the dividend payout ratio having a negative effect on the availability of sustainable financing options in terms of cash flows. The perception that dividend-paying firms are more sustainable may stern from the assumption that firms are willing to "let go of profit" because they have enough to live on. However, this is not the case in many situations since many of the firms that pay dividends still use debt to finance their assets and have ageing payables. In these situations, managers pay dividends, not so much out of financial sufficiency, but out of a desire to temporarily suppress the roar of shareholders' appetite. Shareholders can help improve the financial sustainability of invested companies if they cooperate with management to optimize the retention of free cash flows. Shareholders should not be too hasty to earn short-term dividends but should be willing to sacrifice a substantial amount of income to be ploughed back into the business for expansion. They ought to keep in mind that this money is not lost, as it will help to make their channel of dividend income more sustainable by increasing the longevity of the business.

Lastly, assets acquisitions and maintenance are delicate investment and operating decisions respectively, and should be treated as such. Critical investigations and appraisal should be done before any substantial asset is acquired. Prospective cash flows that can be generated from the utilization of an asset must be large enough to cover its acquisition and maintenance costs by a safe margin for the acquisition of such assets to be justifiable (especially for capital intensive businesses). Assets should be kept in good working condition and replaced on a timely basis when worn out. Strict asset utilization and maintenance policies are essential in achieving this aim. 


\section{IMPLICATIONS}

The correspondence of the results of the analyses with the a priori findings confirms that the free cash flow theory is more applicable in the Nigerian manufacturing sector context than the traditional M \& M theory. This is also confirmed by the positive relationship among asset turnover, dividend payout, and Tobin's $Q$ in the correlation matrix (suggesting that they all act simultaneously in the same direction) in their relationship with cash flows. Although the above relationships seem to align with the stipulations of the free cash flow theory, the negative and partially significant relationship between leverage and dividend payout goes against both the free cash flow theory and the $M$ \& $M$ theory. Both theories suggest a positive relationship that is caused by shareholders' perception of an increase in financial risk. Meanwhile, in the Nigerian context, a negative relationship seems to be the case. The nature of this relationship in other business environments and markets could be a possible topic for further research.

In practical terms, the results of this study hint that the reason for the lack of sustainable cash flows among Nigerian manufacturing companies may be as a result of high dividend payout. The results indicate that the common notion of financing assets using debt financing is not sustainable in the long-run. It may increase profitability in the short-term but is not a sustainable option because, in the long-run, poor investment decisions, debt obligations, and the general increase in financial risk will end up reducing the sustainable cash flows available to managers to finance its investments.

\section{LIMITATIONS AND FUTURE DIRECTIONS}

A major limitation of the study is the sample size. This limitation was due to the unavailability of complete data for several manufacturing companies for the time range of the study. This study found that high leverage and dividend payout reduce the level of sustainable cash flows available to managers for financing investments. However, this doesn't mean that a zero-dividend payout situation is best. Thus, a useful research gap that can be further examined is the optimal level of dividend payout ratio that can maximize sustainable cash flows. Analytical tools like threshold regression may provide useful insights into providing answer to this question.

\section{REFERENCES}

Adeyemi, B. (2011). Bank failure in Nigeria: a consequence of capital inadequacy, lack of transparency and non-performing loans? Banks and Bank Systems, 6(1): 99-109.

Ajmal, M. (2018). Does liquidity, solvency \& efficiency position affect the firm profitability? Empirical evidence from CCl Ltd. Singaporean Journal of Social Science, 1(2): 13-27.

Akinleye, G. T. \& Dadepo, A. O. (2019). Assets utilization and performance of manufacturing firms in Nigeria. International Journal of Business and Management, 14(4): 107-115.

Akpan, A. U., Ahakiri, F. I. \& Ebaye, T. M. (2020). Solvency controlling and return on asset of industrial organizations in Nigeria. European Journal of Management and Marketing Studies, 5(1): 115-137. 


\section{Imhanzenobe \& Adeyemi}

Ali, A. \& Yousaf, S. (2013). Determinants of cash holding in German market. Journal of Business and Management, 12(16): 28-34.

Aniyie, I. A. (2014). Reforms in the Nigerian tax system: An examination of the national tax policy. Port Harcourt Law Journal, 6(1): 111-120.

Arora, L., Kumar, S. \& Verma, P. (2018). The anatomy of sustainable growth rate of Indian manufacturing firms. Global Business Review, 19(4): 1050-1071. https://doi.org/10.1177/0972150918773002

Atoyebi, K., Okafor, B. \& Falana, A. (2014). The global financial meltdown and its effects on manufacturing sector: The Nigerian perspective. Journal of Economics and Sustainable Development, 5(6): 78-90.

Babalola, A. Y. (2013). The effect of firm size on firms profitability in Nigeria. Journal of Economics and Sustainable Development, 4(5): 90-94. https://doi.org/10.5605/IEB.15.4

Baker, H. K. \& Kilincarslan, E. (2018). Why companies do not pay cash dividends: The Turkish experience. Global Finance Journal, 42, 100419. https://doi.org/10.1016/j.gfj.2018.02.005

Baraja, L. \& Yosya, E. A. (2019). Analysis the impact of liquidity, profitability, activity and solvency ratio on change in earnings. Indonesian Management and Accounting Research, 17(1): 1-17. http://dx.doi.org/10.25105/imar.v17i1.4663

Becerra, M. (2008). A Resource-Based Analysis of the Conditions for the Emergence of Profits. Journal of Management, 34(6): 1110-1126. https://doi.org/10.1177/0149206308324323

Bhagat, S., \& Jefferis, R.H. (2005). The econometrics of corporate governance studies. Massachusetts: The MIT Press.

Bodie, Z., Kane, A. \& Marcus, A. J. (2013). Financial statement analysis. In Essentials of investments (9th ed.), 451-459. Taipei: McGraw-Hill/Irwin.

Bowman, W. (2011). Financial capacity and sustainability of ordinary nonprofits. Nonprofit Management and Leadership, 22(1): 37-51. https://doi.org/ 10.1002/nml.20039

Breusch, T. S. \& Pagan, A. (1980). The LM test and its application to model specification in econometrics. Review of Economic Studies, 47(1): 239-253. https://doi.org/10.2307/2297111

Carpenter, R. E. (1995). Finance constraints or free cash flow? Empirica, 22(3): 185- 209. https://doi.org/10.1007/BF01384150

Castro, N. R. \& Chousa, J. P. (2006). An integrated framework for the financial analysis of sustainability. Business Strategy and the Environment, 15(5): 322-333. https://doi.org/10.1002/bse.539

Clor-Proell, S. M., Proell, C. A. \& Warfield, T. D. (2014). The effects of presentation salience and measurement subjectivity on nonprofessional investors' fair value judgments. Contemporary Accounting Research, 31(1): 45-66. https://doi.org/10.1111/1911-3846.12041

Costicã, V. (2014). Financial sustainability of the company. Ovidius University Annals, Economic Sciences Series, 14(1): 775779.

Crutchley, C. E. \& Hansen, R. S. (1989). A test of the agency theory of managerial ownership, corporate leverage, and corporate dividends. Financial Management, 18(4): 36-46. https://doi.org/10.2307/3665795

Dechow, P. \& Skinner, D. (2000), Earnings management: Reconciling the views of accounting academics, practitioners and regulators. Accounting Horizons, 14(2): 235-250. https://doi.org/10.2308/acch.2000.14.2.235

Egboro, E. M. (2016). The 2008/2009 banking crisis in Nigeria: The hidden trigger of the financial crash. British Journal of Economics, Management and Trade, 12(2): 1-16. https://doi.org/10.9734/BJEMT

Ekeocha, P. C., Ekeocha, C. S., Malaolu, V. \& Oduh, M. O. (2012). Revenue implications of Nigeria's tax system. Journal of Economics and Sustainable Development, 3(8): 206-215.

Ferreira, M. A. \& Vilela, A. S. (2004). Why do firms hold cash? Evidence from EMU countries. European Financial Management, 10(2): 295-319. https://doi.org/10.1111/j.1354-7798.2004.00251.x

Ghyasi, A. (2017). An investigation of the relationship between earnings management and financial ratios (panel data approach). International Journal of Economics and Financial Issues, 7(1): 608-612.

Giriati, Z. (2016). Free cash flow, dividend policy, investment opportunity set, opportunistic behavior and firm's value: A study about agency theory). Procedia - Social and Behavioral Sciences, 219, 248-254. https://doi.org/10.1016/j.sbspro.2016.05.013

Harris, M. \& Raviv, A. (1990). Capital structure and the informational role of debt. Journal of Finance, 45(2): 321-349. https://doi.org/10.1111/j.1540-6261.1990.tb03693.x

Healy, M. P. \& Wahlen, J. M. (1999), A review of the earnings management literature and its implications for standard setting. Accounting Horizons, 13(4): 365-383. https://doi.org/10.2308/acch.1999.13.4.365

Imhanzenobe, J. O. (2019). Operational efficiency and financial sustainability of listed manufacturing companies in Nigeria. Journal of Accounting and Taxation, 11(1): 17-31. https://doi.org/10.5897/JAT2018.0329

Imhanzenobe, J. O. (2020). Managers' financial practices and financial sustainability of Nigerian manufacturing companies: Which ratios matter most?. Cogent Economics and Finance, 8(1): 1724241. https://doi.org/10.1080/23322039.2020.1724241

Jensen, M. C. (1986). Agency costs of free cash flow, corporate finance, and takeovers. American Economic Review, 76(2): 323-329.

Jordão, R. \& Almeida, V. (2017). Performance measurement, intellectual capital and financial sustainability. Journal of Intellectual Capital, 18(3): 643-666. https://doi.org/10.1108/JIC-11-2016-0115

Kadioglu, E. \& Yilmaz, E. A. (2017). Is the free cash flow hypothesis valid in Turkey? Borsa Istanbul Review, 17(2): 111-116. https://doi.org/10.1016/j.bir.2016.12.001

Kao, C. (1999). Spurious regression and residual-based tests for cointegration in panel data. Journal of Econometrics, 90(1): 1-44. https://doi.org/10.1016/S0304-4076(98)00023-2 
Kariuki, S. N., Namusonge, G. S. \& Orwa, G. O. (2015). Determinants of corporate cash holdings: evidence from private manufacturing firms in Kenya. International Journal of Advanced Research in Management and Social Sciences, 4(6): 15-33.

Karpavič ius, S. \& Yu, F. (2017). How institutional monitoring creates value: Evidence for the free cash flow hypothesis. International Review of Economics and Finance, 52, 127-146. https://doi.org/10.1016/j.iref.2017.10.016

Khan, A., Kaleem, A. \& Nazir, M. (2012). Impact of Financial Leverage on Agency cost of Free Cash Flow: Evidence from the Manufacturing sector of Pakistan. Journal of Basic and Applied Scientific Research, 2(7): 6694-6700.

Kogan, L. \& Papanikolaou, D. (2014). Growth opportunities, technology shocks, and asset prices. Journal of Finance, 69(2): 675-718. https://doi.org/10.1111/jofi.12136

Komolafe, B. (2019). CBN debits banks N650bn for loan to deposit ratio failure. Retrieved May 5, 2020, from https://www.vanguardngr.com/2019/12/cbn-debits-banks-n650bn-for-loan-to-deposit-ratio-failure/

Kumar, D. (2016). Building sustainable competitive advantage: Through executive enterprise leadership. London: Routledge.

Lang, L., Ofek, E. \& Stulz, R. M. (1996). Leverage, investment, and firm growth. Journal of Financial Economics, 40(1): 3-29. https://doi.org/10.1016/0304-405X(95)00842-3

Linares-Mustarós, S., Coenders, G. \& Vives-Mestres, M. (2018). Financial performance and distress profiles. From classification according to financial ratios to compositional classification. Advances in Accounting, 40, 1-10. https://doi.org/10.1016/j.adiac.2017.10.003

Maheshwari, Y. \& Rao, K. V. (2017). Determinants of corporate cash holdings. Global Business Review, 18(2): 416-427. https://doi.org/10.1177/0972150916668610

McDonough, R., Panaretou, A., \& Shakespeare, C. (2020). Fair value accounting: Current practice and perspectives for future research. Journal of Business Finance and Accounting, 47(3): 303-332. https://doi.org/10.1111/jbfa.12447

Modigliani, F. \& Miller, M. H. (1958). The Cost of Capital, Corporate Finance, and the Theory of Investment. American Economic Review, 48(4): 261-297.

Mougoué, M. \& Mukherjee, T. K. (1994). An investigation into the causality among firms' dividend, investment, and financing decisions. Journal of Financial Research, 17(4): 517-530. https://doi.org/10.1111/j.1475-6803.1994.tb00162.x

Mulford, C. W. \& Comiskey, E. E. (2005). Creative cash flow reporting: Uncovering sustainable financial performance. New York: John Wiley \& Sons.

Myers, S. C. (2001). Capital structure. Journal of Economic Perspectives, 15(2): 81-102.

Nairametrics (2020). CBN debits banks N1.4 trillion for failing to meet CRR targets. Retrieved May 5, 2020, from https://nairametrics.com/2020/04/24/breaking-cbn-debits-banks-n1-4-trillion-for-failing-to-meet-crr-targets/

Najid, N. A., \& Rahman, R. A. (2011). Government ownership and performance of Malaysian government-linked companies. International Research Journal of Finance and Economics, 61(1): 1450-2887.

Nan, L. (2019). On the financing regulation of stock market and the optimal capital structure of listed companies. The Frontiers of Society, Science and Technology, 1(7): 27-36.

Opler T., Pinkowitz L., Stulz R. \& Williamson R. (1999): The determinants and implications of corporate cash holdings. Journal of Financial Economics, 52(1): 3-46. https://doi.org/10.1016/S0304-405X(99)00003-3

Oyewale, B. \& Adewale, B. (2014). Sustainability of microfinance institutions: A comparative case study of Kwara State, Nigeria. Journal of Business and Organizational Development, 6(2): 11-25.

Ozkan, A. \& Ozkan, N. (2004): Corporate cash holdings: An empirical investigation of UK companies, Journal of Banking and Finance, 28(9): 2103-2134. https://doi.org/10.1016/j.jbankfin.2003.08.003

Payne, B. C., Wong, R. \& Payne, J. B. (2016). On the risk return characteristics of those firms experiencing the highest free cash flow yields. Southwestern Economic Review, 43, 1-13.

Pesaran, M. H. (2006). Estimation and inference in large heterogeneous panels with cross section dependence. Econometrica, 74(4): 967-1012. https://doi.org/10.1111/j.1468-0262.2006.00692.x

Pinkowitz L., Stulz R. \& Williamson R. (2006): Does the contribution of corporate cash holdings and dividends to firm value depend on governance? A cross-country analysis. The Journal of Finance, 61(6): 2725-2751. https://doi.org/10.1111/j.1540-6261.2006.01003.x

Roychowdhury, S. (2006), Earnings management through real activities manipulation. Journal of Accounting and Economics, 42(3): 335-370. https://doi.org/10.1016/j.jacceco.2006.01.002

Singh, K. \& Misra, M. (2019). Financial determinants of cash holding levels: An analysis of Indian agricultural enter-prises. Agricultural Economics- Czech, 65(5): 240-248. https://doi.org/10.17221/240/2018-AGRICECON

Smith, C. W. \& Watts, R. L. (1992). The investment opportunity set and corporate financing, dividend, and compensation policies. Journal of Financial Economics, 32(3): 263-292. https://doi.org/10.1016/0304-405X(92)90029-W

Vogt, S. C. (1994). The cash flow/investment relationship: Evidence from U.S. manufacturing firms. Financial Management, 23(2): 3-20. https://doi.org/10.2307/3665735

Wällstedt, N., Grossi, G. \& Almqvis, R. (2014). Organizational solutions for financial sustainability: A comparative case study from the Swedish municipalities. Journal of Public Budgeting, Accounting and Financial Management, 26(1): 181-218.

Watts, R. L. \& Zimmerman, J. L. (1990). Positive accounting theory: A ten year perspective. Accounting Review, 65(1): 131156. 
Imhanzenobe \& Adeyemi

Appendix-1

\begin{tabular}{cccccc}
\hline & DTE & AST & DPR & TBQ & FSZ \\
\hline AST & 0.081342 & 1.000000 & & & \\
DPR & $-0.161924^{\dagger}$ & $0.280488^{* *}$ & 1.000000 & & \\
TBQ & -0.109977 & $0.360968^{* * *}$ & $0.248953^{* *}$ & 1.000000 & \\
FSZ & $0.297782^{* *}$ & $-0.384407^{* * *}$ & 0.036880 & -0.070977 & 1.000000 \\
\hline
\end{tabular}

Source: Authors' Computation

Note: ${ }^{\dagger},{ }^{* *}$ and ${ }^{* * *}$ denote level of significance at $10 \%, 1 \%$ and $.10 \%$, respectively.

Table 4. Correlation Matrix 


\begin{tabular}{lccc}
\hline \multicolumn{4}{c}{ First Difference (t-statistics) } \\
\hline Variables & Levin, Lin and Chu & $\begin{array}{c}\text { Im, Pesaran and } \\
\text { Shin w-stat }\end{array}$ & $\begin{array}{c}\text { ADF }- \text { Fisher } \\
\text { Chi-square }\end{array}$ \\
\hline FCY & $-12.3058^{* * *}$ & $-5.94418^{* * *}$ & $93.8874^{* * *}$ \\
DTE & $-108016^{* * *}$ & $-19631.5^{* * *}$ & $86.5960^{* * *}$ \\
AST & $-10.0039^{* * *}$ & $-3.57844^{* * *}$ & $79.1833^{* * *}$ \\
DPR & $-7.51568^{* * *}$ & $-2.72629^{* * *}$ & $56.8700^{* * *}$ \\
TBQ & $-11.4265^{* * *}$ & $-4.34373^{* * *}$ & $86.2985^{* * *}$ \\
FSZ & $-14.7221^{* * *}$ & $-3.99438^{* * *}$ & $79.8903^{* * *}$ \\
\hline $\begin{array}{l}\text { Source: Authors' Computation } \\
\text { Note: }\end{array}$ & & \\
\end{tabular}

Table 5. Panel Unit Root Test 
Imhanzenobe \& Adeyemi

Appendix-III

\begin{tabular}{ccc}
\hline & t-Statistic & Prob. \\
ADF & -2.757060 & $0.0029^{* *}$ \\
\hline Residual variance & 0.028383 & \\
HAC variance & 0.011753 & \\
\hline
\end{tabular}

Source: Authors' Computation

Note: ${ }^{* *}$ denotes level of significance at $1 \%$.

Series: FCY DTE AST DPR TBQ FSZ

Table 6. Kao Residual Cointegration Test 


\begin{tabular}{|c|c|c|}
\hline Regressors & Coefficient & $t$-Statistic \\
\hline DTE & -0.002792 & $-3.744432^{* * *}$ \\
\hline $\begin{array}{l}\text { AST } \\
\text { DPR }\end{array}$ & $\begin{array}{r}0.360610 \\
-0.209084\end{array}$ & $\begin{array}{c}2.204802^{*} \\
-2.385072^{*}\end{array}$ \\
\hline TBQ & -0.024724 & -1.321044 \\
\hline FSZ & 0.247335 & 0.560961 \\
\hline $\mathrm{R}^{2}$ & 0.552285 & \\
\hline Long-run variance & 0.008861 & \\
\hline
\end{tabular}

Table 7. Panel Fully Modified Ordinary Least Square Model 
Imhanzenobe \& Adeyemi

Appendix-V

\begin{tabular}{c|ccc}
\hline Test & Statistic & d.f & Prob. \\
\hline Breusch-Pagan Chi-square & 57.35092 & 153 & 0.9940 \\
Pearson LM Normal & -0.494435 & & 0.6210 \\
Pearson CD Normal & -0.282434 & & 0.7776 \\
\hline
\end{tabular}

Source: Authors' Computation

Note: ${ }^{* * *}$ denotes level of significance at $0.1 \%$

Table 8. Cross-Sectional Dependence Test for Estimated FMOLS Model 